\title{
SYMPOSIUM ON DRUG DECRIMINALIZATION, LEGALIZATION, AND INTERNATIONAL LAW
}

\author{
TOWARDS GLOBAL GOVERNANCE: THE INADEQUACIES OF THE UN DRUG \\ CONTROL REGIME \\ Antonia Eliason ${ }^{*}$ and Robert Howse ${ }^{* *}$
}

Human rights and the UN drug control regime have long had an uneasy relationship, which is evident today in the tensions that exist between criminal justice reform advocates, the institutions of the UN drug control regime, and economic interests that stand to benefit from decriminalization and legalization efforts. The UN drug control regime's relationship with human rights cannot be properly discussed without acknowledging its colonial and racist roots. From the earliest agreement on drug control in 1909, born out of the crisis of opium dependency caused by the forced opening of China to trade in opium by the British, ${ }^{1}$ to the 1988 United Nations Convention Against Illicit Traffic in Narcotic Drugs and Psychotropic Substances, which was a product of America's war on drugs, ${ }^{2}$ international efforts to regulate drugs have never been for the benefit of those who have suffered the most from both the supply of drugs and its criminalization. The war on drugs has been a global war from the beginning, arising out of colonial structures that centered white/European racial dominance. The inadequacies of the international drug regime and current efforts to reform it are rooted in this historical legacy. In light of this, we argue that efforts by international bodies to center human rights in the discussion on reforming the UN drug control regime are, so far, insufficient. Only through recognizing the power imbalances at play can we advance the possibility of a system that values individuals and responds to a changing landscape where corporate interests are coming to the table in the context of decriminalization and legalization.

\section{The Punitive UN Drug Control Regime}

The UN drug control regime has proven ineffective in both its response to legal questions relating to national decriminalization/legalization of cannabis, and in its handling of the opioid crisis. At its core a punitive regime, with an individualized focus on consumers and distributors of illicit drugs, the drug control regime has failed to adequately address the elephant in the room: the multinational pharmaceutical industry. The

* Associate Professor at the University of Mississippi School of Law.

** Lloyd C. Nelson Professor of International Law at NYU Law School.

${ }^{1}$ Katherine Pettus, Colonial Roots of the Global Pandemic of Untreated Pain, in The War on Drugs and the Global Colour Line 196, 199-200 (Kojo Koram ed., 2019).

${ }^{2}$ David P. Stewart, Internationalizing the War on Drugs: The UN Convention Against Illegal Traffic in Narcotic Drugs and Psychotropic Substances, 18 Denv. J. Int'L L. \& POL’y 387 (1990).

(C) Antonia Eliason and Robert Howse 2020. This is an Open Access article, distributed under the terms of the Creative Commons Attribution licence (http://creativecommons.org/licenses/by/4.0/), which permits unrestricted re-use, distribution, and reproduction in any medium, provided the original work is properly cited. 
pharmaceutical industry has played a central role in creating the opioid crisis and is an active player in the legal cannabis sector. ${ }^{3}$ Multinational tobacco and alcohol companies are also already actively involved in legal cannabis. ${ }^{4}$

In our article "A Higher Authority: Canada's Cannabis Legalization in the Context of International Law," we explored justifications in human rights law for Canada's legalization of recreational cannabis, and how those justifications interacted with the drug control regime, which has remained hostile to this project. ${ }^{5}$ Not long after the publication of our article, in March 2019, a coalition of UN member states and various UN entities, including the UN Development Programme, the World Health Organization (WHO) and the Joint UN Programmes on HIV and AIDS, released the International Guidelines on Human Rights and Drug Policy, the result of a multi-year process of consultation and deliberation. ${ }^{6}$ The Guidelines are based on both soft and hard international law sources.

It does not require too much reading between the lines to locate the impetus for this initiative in frustration with the drug control regime's unresponsiveness to human rights concerns, especially to the case for moving towards decriminalization. Thus, the document acknowledges "tensions" between "drug control and human rights obligations." "The acknowledgement of tensions, however, does not lead to a project of radically reforming the drug control regime, yet it is not terribly out of sync with human rights-positive reforms of drug policy being undertaken in numerous countries, as well as the decisions of domestic and regional tribunals on drug laws and human rights. Instead, the Guidelines take the approach of "concurrent obligations" and seek to influence national drug policy within the constraints of the drug conventions, at the core of which is an international legal obligation of criminal sanctions.

\section{Reconciling Drug Control with Human Rights}

One can look at this moderate reformist position adopted in the Guidelines from two points of view. One is that of realism. The regime is, as already noted, highly resistant to reform, and deeply entwined with racialized and colonialized criminalization measures. The strategy of asking governments to reconcile their obligations under the drug control regime with international human rights responsibilities allows for the possibility that, where the domestic political will for reforms exists, these can be presented as a human rights-friendly application of the drug control regime. Despite an initial threat by Russia to challenge Canada's legalization of recreational cannabis in the International Court of Justice as a violation of the drug conventions, the de facto interpretive latitude for states is considerable when they present their approach as a synthesis of drug control and human rights obligations. The drug control regime enters dangerous territory when pronouncing on national policies that are explicitly presented as balancing human rights obligations with obligations under the drug conventions. To reject such balancing would encroach onto the territory of another specialized international legal regime, the human rights regime, which has greater prominence in the public arena.

An alternative, more critical, perspective would be that the Guidelines risk legitimizing the essential features of the drug control regime from the perspective of international human rights law. Apart from the reference to "tensions," the document lacks any critique of the regime. A more candid approach would be for countries like Canada

\footnotetext{
${ }^{3}$ Kris Krane, Cannabis Attracts Big Tobacco, Alcohol, and Pharma. Which Big Industries Will Join Next?, Forbes (Dec. 19, 2018).

${ }^{4}$ David Gelles, When the Markers of Marlboro and Corona Get into Marijuana, N.Y. Times (Dec. 12, 2018).

5 Antonia Eliason \& Robert Howse, A Higher Authority: Canada's Cannabis Legalization in the Context of International Law, 40 MiCH. J. INT'L L. 327, 327 (2019).

${ }^{6}$ UN Dev. Programme, International Guidelines on Human Rights and Drug Policy (Mar. 14, 2019) [hereinafter International Guidelines on Human Rights and Drug Policy].

${ }^{7}$ Id. arts. $\mathrm{I}(2), \mathrm{V}(1)(\mathrm{i})$.
} 
(as some commentators have suggested) to denounce the drug conventions to the extent that the regime does not accommodate legalization, especially in light of the serious human rights violations implicated by the criminal enforcement approach privileged by the drug control regime. ${ }^{8}$ Not only does the drug control regime not acknowledge the terrible social costs of the criminal enforcement model, it offers only resistance to efforts to find alternatives, with occasional recognition of the reality that governments are nonetheless moving forward with reforms. Such concessions are transparent efforts to cabin these reforms so as to preserve the centrality of the criminal enforcement model. In light of the origins of the drug control regime, this is unsurprising.

At the risk of irony, the most overtly radical element in the Guidelines is the categorical affirmation that states may " $[\mathrm{u}]$ tilise the available flexibilities in the drug control conventions to decriminalize the possession, purchase, or cultivation of controlled substances for personal consumption." "Not even this very modest degree of departure from the criminal enforcement model is indicated by the Guidelines as required or even desirable for fulfilling human rights. It is merely permissible under the Guidelines.

This contrasts with how the Guidelines address medical uses of controlled drugs. Here, the Guidelines endorse legal access for medical purposes, including "pain relief" as part of the right to health in international law. ${ }^{10}$ This strong framing of the right to medical access as a human right is at odds with how the UN drug control regime has viewed these issues, having, for instance, failed to fully endorse recommendations concerning the medical value of cannabis, much less actually to remove medical cannabis from the restrictions. The UN Commission on Narcotic Drugs (CND) was to have voted in March 2019 on the global rescheduling of cannabis based on a recommendation from the WHO that cannabis and related substances, like CBD and THC, be rescheduled. The vote was postponed. ${ }^{11}$ In March 2020, the CND again postponed the vote, leaving the international legal status of national legalization measures, such as Canada's 2018 Cannabis Act, uncertain. ${ }^{2}$ The vote has now been scheduled for December 2020. ${ }^{13}$

\section{Affirming the Primacy of Human Rights Norms}

While the basis of the Guidelines appears to be "concurrent obligations" under the drug conventions and under international human rights law, the provisions on "Treaty Interpretation Principles" at least acknowledge the possibility of a conflict of obligations that cannot be avoided through harmonization of drug control treaties and human rights obligations: "Two diverging commitments must ... be harmonized as much as possible so they produce effects that are fully in accordance with existing human rights law." 14 Although this statement falls short of asserting a hierarchy of norms with human rights obligations having superiority over drug control treaty obligations, it stipulates interpretation that gives primacy to human rights norms. This is, albeit subtly, a challenge to the interpretive hegemony over the drug conventions by the drug control institutions.

A related challenge arises from language in the Guidelines that states that nothing in the drug conventions shall be interpreted as authorizing any act that either in purpose or effect violates human rights "to a greater extent than

\footnotetext{
8 Álvaro Santos, Drug Policy Reform in the Americas: A Welcome Challenge to International Law, 114 AJIL UnBound 301 (2020).

${ }^{9}$ International Guidelines on Human Rights and Drug Policy, supra note 6, art. II(1)(v).

${ }^{10} \mathrm{Id}$. art. II(1.3)(vii).

${ }^{11}$ UN Off. on Drugs \& Crime, WHO Scheduling Recommendations on Cannabis and Cannabis-Related Substances (Mar. 14, 2019).

12 Alexander Lekhtman, UN Commission on Narcotic Drugs Once Again Postpones Key Cannabis Vote, FiLTER Mag. (Mar. 5, 2020).

13 Alfredo Pascual, UN Body Preparing for December Vote on WHO Cannabis Recommendations Despite Coronavirus, MARIJuANA Bus. DaILY (May 28, 2020).

${ }^{14}$ International Guidelines on Human Rights and Drug Policy, supra note 7, art. V(1)(iii) (emphasis added).
} 
is specifically provided in [the drug conventions]." 15 This clause invokes the notion that any limits on rights must be explicitly stated and subject to justification on accepted grounds. This could lead to a step beyond harmonious interpretation-i.e., not giving effect to any rights-infringing provision of the drug conventions where the treaty does not specifically state that a limit to rights is intended or does not state the nature and scope of that limit. A corollary is that a state may not use the drug conventions themselves as a justification for limiting rights (whether in domestic, regional, or international law) since specific rights limitations are not stated in those instruments. This further erodes the capacity of the drug control regime to inhibit or restrain rights litigation-driven efforts at reform of drug laws. Moreover, to be compatible with international human rights obligations, the Guidelines indicate that any limits to rights must be justified in accordance with certain policy objectives and principles, including non-discrimination in the application of the rights-limiting law. This is pervasively violated in the way drug laws are applied in many jurisdictions. The Guidelines also state that any limitation "shall be interpreted strictly and in favour of the right at issue." 16 These constraints offer a human rights-based perspective through which to interpret the drug treaties, but ultimately, the Guidelines fall short.

The Guidelines remain just that: guidelines and not legal prescriptions. While they succeed in navigating the potential conflict between enforcement of the drug conventions and human rights obligations, they also fall short in advocating for deeper structural changes to the regime, particularly decriminalization of controlled substances. ${ }^{17}$ The Guidelines operate within the structure of the existing drug control regime. As we so often see across law and politics, using deeply flawed systems to advocate for real change rarely results in the desired change, and at times undermines more creative solutions to effectively address systemic problems.

\section{Decriminalization and Distributive Justice}

While the legality of comprehensive legalization measures is debatable under the drug control regime, the financial rewards from investing in legal recreational and medical drugs are unmistakable. In the case of the Guidelines, their focus is on drug dependence treatment, changes to drug laws, and other measures necessary to rectify human rights abuses that have occurred under the guise of enforcing drug laws. There is no mention, even in preambular language, of the role that pharmaceutical companies have played in creating drug dependencies. Much as the British Empire forced opium upon the people subjugated by its colonial rule as a means of economic dominance, the pharmaceutical industry pushed its products through legal means and trade channels upon millions of people around the world. ${ }^{18}$ Human rights in relation to the drug trade is not only about reducing prison sentences but requires acknowledging the role that the pharmaceutical industry has played in peddling its products to unsuspecting consumers. Though the rise of corporate responsibility in international law may alter this somewhat, the language of human rights typically focuses on the actions of states and their agents, rather than on the conduct of corporate entities, which reflects the classical paradigms of international law and the central role that states play in traditional international law.

Similar issues exist with multinational tobacco and alcohol companies, which are investing heavily in newly legal cannabis markets. These well-capitalized corporate initiatives, often protected by intellectual property rights that, where enforceable, create monopoly rents, have the potential to continue the disenfranchisement of minority and indigenous communities that have most suffered at the hands of punitive drug policies. These initiatives limit the

${ }^{15}$ Id. art. V(2)(i).

${ }_{10}^{16} \frac{I}{I d}$ art. $\mathrm{V}(2)(\mathrm{iv})(\mathrm{c})$.

17 Paulette Lloyd \& Beth A. Simmons, Framing a New Transnational Legal Order: The Case of Human Trafficking, in TransNational LegaL ORDERS 400-438 (Terry C. Halliday \& Gregory Shaffer eds., 2015).

${ }^{18}$ Sarah DeWeerdt, Tracing the US Opioid Crisis to Its Roots, NAture (Sept. 11, 2019). 
ability of communities to participate in nascent legalized markets. International human rights law no longer applies once punitive drug laws are removed and those incarcerated under these laws are released. When legal markets open up, those disproportionally affected by drug policies should be given opportunities to participate in building new businesses. In reality, unless there is strong domestic support for programs to benefit those communities after legalization, large corporate entities will step in and dominate newly legal markets. ${ }^{19}$

There is still room for international law to be useful in the realm of distributive justice with respect to decriminalization, even after the fact and outside the human rights framework. Clear guidance from the drug control regime that decriminalization of certain substances is legal, notably cannabis for personal use, would open up a path to participation by smaller actors in the global market. However, the unwillingness of the CND to act on rescheduling cannabis-notwithstanding WHO recommendations and decriminalization by a growing number of countries - is troubling. We are left with a complex, conflicting, and overlapping set of international and domestic drug laws that are difficult to negotiate without costly legal advice. Absent international guidance, multinational pharmaceutical, tobacco and alcohol companies and their lawyers will be the actors best able to navigate these systems and thus corner legal drug markets. Minorities and indigenous communities who should be provided with opportunities to invest in a newly legal market will be limited in their ability to participate.

The war on drugs is international, colonial, and racist, ${ }^{20}$ and the UN drug regime has been an integral part of that effort. A more just and equitable international drug regime would require a global governance network, particularly between national public health authorities and researchers, to steer legalization towards better public health outcomes, and address the risks of profit-maximizing multinational corporations controlling how legal drugs are made available to consumers. Further, transitional justice and the imperative of reparation for those who have been victims of the racist and colonialist drug regime must be addressed. The punitive focus of the UN drug regime together with the outsized influence of the multinational pharmaceutical industry in the WHO have arguably prevented the emergence of such a structure.

\section{Conclusion}

One should not underestimate the policy space that can be won through imaginative human rights-positive interpretation of the flexibilities of the drug control regime. In "A Higher Authority," we show how one such interpretation could reconcile Canada's legalization scheme for cannabis with the UN drug conventions. ${ }^{21}$ Yet, while the Guidelines attempt to enable drug law reforms for better human rights outcomes, they never break free from the imaginary of the conventions, explicitly eschewing the notion of providing a better human rights-enhancing or -protecting model for drug law and policy (with the possible exception of medical uses). This is especially apparent in the failure of the Guidelines to address what we regard as the most pressing justice issue associated with reform - the need for transitional or restorative justice measures for those who have suffered human rights abuses under the prior criminal enforcement-based regime, including amnesties and pardons, and measures that provide the victims of failed drug policies with opportunities to benefit from the economic possibilities created through legalization. Decriminalization of possession and related acts of personal use is the closest the Guidelines come to envisaging a regime where the failed carceral state is replaced by a different paradigm for addressing the health and social challenges of recreational drug use, one driven by the demand for justice.

\footnotetext{
${ }^{19}$ Krane, supra note 3 and Gelles, supra note 4.

20 See, e.g., Tanzil Chowdhury, Policing the Black Party': Racialized Drugs Policing at Festivals in the UK, Koram, supra note 1, at 48; Evandro Piza Duarte \& Felipe da Silva Freitas, Racism and Drug Policy: Criminal Control and the Management of Black. Bodies by the Brazilian State, in Koram, supra note 1, at 66; Asmin Fransiska, Racism and Social Injustice in War on Drugs Narratives in Indonesia, in Koram, supra note 1, at 177.

${ }^{21}$ Eliason \& Howse, supra note 5, at 351-56.
} 